\title{
Seroprevalence Studies of Brucellosis among Human using Different Serological Tests
}

\author{
Vijay Sharma ${ }^{1}$, H.K. Sharma ${ }^{1}$, Subha Ganguly ${ }^{3 *}$, Sindhu Berian ${ }^{2}$ and M.A. Malik ${ }^{1}$ \\ ${ }^{1}$ Department of Veterinary Public Health and Epidemiology, \\ ${ }^{2}$ Department of Veterinary Medicine, Faculty of Veterinary Science and Animal Husbandry, \\ Sher-e-Kashmir University of Agricultural Sciences and Technology - Jammu (SKUAST - J), \\ R.S. Pura, Jammu - 181102, J \& K, India \\ ${ }^{3}$ Department of Veterinary Microbiology, Arawali Veterinary College (Affiliated with Rajasthan \\ University of Veterinary and Animal Sciences, Bikaner), N.H. - 52 Jaipur Road, V.P.O. Bajor, \\ Sikar-332001, Rajasthan, India \\ *Corresponding author
}

\section{A B S T R A C T}

\section{Keywords \\ Brucellosis, \\ Sero-prevalence, human, RBPT, STAT, I-ELISA. \\ Article Info \\ Accepted: \\ 17 April 2017 \\ Available Online: \\ 10 May 2017}

A study was conducted to determine the prevalence of Brucellosis in humans in and around border areas of Jammu, J\&K, India using different serological tests viz., RBPT, STAT and I-ELISA. A total of 75 sera samples from humans were tested by RBPT, STAT and I-ELISA. In humans, overall prevalence of $1.33 \%$ was recorded. Age-wise 36-50 yr persons while sex-wise males had higher prevalence.

\section{Introduction}

Brucella has always been of zoonotic importance all though the history and clinical conditions synonymous with brucellosis have been described since the time of Roman Empire (Godfroid et al., 2005). Cocco-like forms resembling Brucella have been detected in carbonized cheese from the Roman era (Capasso, 2002). But, it was in 1887, when Sir David Bruce isolated the organism from the spleen of a British soldier who died from the Mediterranean fever in Malta and named it as Micrococcus melitensis.
Later, it was renamed Brucella melitensis in the honor of Sir David Bruce (Godfroid et al., 2005).

Among all species of Brucella, B. melitensis is considered to be the most pathogenic to humans (Benkirane, 2006) causing maximum number (up to $90 \%$ ) of human cases (Corbel, 1997) followed by B. abortus and B. suis. Brucellosis is an occupational direct anthropozoonosis. Public health significance of brucellosis is not only because of its status 
as one of the world's major zoonoses but also because it causes a serious reduction in availability of quality food, especially the animal proteins. It also poses a serious threat to livestock economy by causing abortion, loss of offspring, infertility and reduction in milk yield.

Most cases in humans are caused by contact with infected animals or animal products, such as unpasteurized milk and cheese prepared from infected unpasteurized milk (Papaps et al., 2005).

Thus, due to paucity of epidemiological data of humans brucellosis in and around border areas of Jammu region and unavailability of simple and sensitive method for diagnosis of humans and goat brucellosis, this study has been proposed with the objective of studying the prevalence of brucellosis in humans in and around border areas of Jammu.

\section{Materials and Methods}

A total of 75 human sera samples were collected from in and around border areas of Jammu region. The distribution of collected samples as per the area and species has been shown in table 1. In humans, the samples were collected from occupationally exposed groups viz., veterinarians and patients with history of pyrexia of unknown origin (PUO), arthralgia etc. along with their age and sex particulars (Tables 1 and 2). All samples were subjected to RBPT, STAT and I- ELISA tests.

In humans, blood collection was done using sterilized disposable syringes $(5 \mathrm{ml})$ and serum separated by same procedure as adopted in animals. The serum samples collected were aliquoted and stored at $-20^{\circ} \mathrm{C}$ till used.

The RBPT was performed according to the method described by Alton et al., (1975). The Rose Bengal Antigen was procured from Biological Products (BP) Division, IVRI.
Before the test, both, serum and antigen were allowed to come at room temperature. Then, the test was performed by mixing $30 \mu \mathrm{l}$ each of serum and antigen on a glass plate. With continuous shaking, the plates were looked for any appearance of agglutination. Appearance of agglutination within $4 \mathrm{~min}$ of mixing of reagents was taken as positive while absence of agglutination was recorded as negative result.

The test was performed in clean glass tubes (14 mm x $100 \mathrm{~mm}$ ) according to the method described by Alton et al., (1975). The contents of tube were thoroughly mixed followed by incubation at $37^{0} \mathrm{C}$ for 18 hours. After incubation, the tubes were kept at room temperature for $1 / 2$ an hour followed by interpretation of results. A titre of $\geq 40 \mathrm{IU}$ was taken as positive in goat while $\geq 80 \mathrm{IU}$ was the cutoff in human.

The ELISA was performed as per the method standardized by Singh (2008), using S-LPS extracted from B. abortus S 99.

Smooth LPS was extracted from heat-killed cells of B. abortus, by the hot water/hot phenol method as described by OIE with minor modifications (2008a)

For the extraction, $5 \mathrm{~g}$ of lyophilized cells of B. abortus strain 99 was suspended in $170 \mathrm{ml}$ of distilled water (DW) and heated to $66^{\circ} \mathrm{C}$. An equal volume of phenol $(90 \% ; \mathrm{v} / \mathrm{v})$ in $\mathrm{DW}$, also heated to $66^{\circ} \mathrm{C}$, was added and the solution was stirred continuously for $20 \mathrm{~min}$. It was then cooled to $4^{\circ} \mathrm{C}$ and centrifuged at $12,000 \mathrm{~g}$ for $20 \mathrm{~min}$ at $4^{\circ} \mathrm{C}$. The phenol phase (bottom layer) was recovered and filtered through Whatman \#1 to which three volumes of chilled methanol reagent was added. It was mixed thoroughly and left to precipitate at $4^{\circ} \mathrm{C}$ for $2 \mathrm{~h}$. The precipitate was recovered by centrifugation at $12,000 \mathrm{x} \mathrm{g}$ at $4^{0} \mathrm{C}$ and resuspended in the $80 \mathrm{ml}$ of DW and centrifuged at $6,000 \mathrm{~g}$ for $20 \mathrm{~min}$. The pellet 
was re-suspended in $80 \mathrm{ml}$ of DW and stirred at $4^{\circ} \mathrm{C}$ overnight. The solution was then centrifuged at $10,000 \mathrm{~g}$ for $15 \mathrm{~min}$ at $4{ }^{\circ} \mathrm{C}$ and the supernatant was decanted. Another $80 \mathrm{ml}$ of DW was added to the pellet, which was then stirred for $1 \mathrm{~h}$ and centrifuged as before.

The two supernatants were pooled, filtered through membrane filter $(0.3 \mu \mathrm{m})$, and 50 $100 \mu \mathrm{g}$ each of ribonuclease, deoxyribonuclease and proteinase $\mathrm{K}$ were added. This mixture was incubated for $18 \mathrm{~h}$ at $20^{\circ} \mathrm{C}$. It was re-precipitated with methanol and re-suspended as above in $2 \mathrm{ml}$ of DW. The solution was dialyzed extensively against DW until free of phenol.

The resultant antigen was lyophilized, weighed and resuspended in DW to give $1 \mathrm{mg}$ LPS/ $\mathrm{ml}$. This was finally freeze dried in $1 \mathrm{ml}$ volume and stored at $4^{\circ} \mathrm{C}$ for future use. The cut-off values for I-ELISA were determined in terms of PP value (percent positivity); and in case of goats it was 58 and in humans is 67. The serum samples of goats and humans having $\mathrm{PP}$ value $>58$ and $>67$ respectively, were recorded as positive. In the test proper the positive and negative controls along with a conjugate control were always included in each microtitre plate.

Anti-human conjugate was procured from Bangalore Genei.

The relative sensitivity and relative specificity of the test was calculated using the method described by Mcdiarmid and Hellstrom (1987).

Relative Sensitivity $(\%)=$

Serum samples positive to both test compared and standard test $\times 100$

Serum samples positive to standard test
Relative Specificity $(\%)=$

Serum samples negative to

both test compared and standard test $\mathrm{x} 100$

Serum samples negative to standard test

The kappa value, odd's ratio, accuracy, predictive value and likelihoodratio were calculated using JavaStat-2-way Contingency Table Analysis at $95 \%$ confidence interval.

\section{Results and Discussion}

In the present study, a total of 75 sera samples originated from veterinarians / animal handlers and the patients with history of PUO, arthralgia, joint pain etc. The distribution of collected samples as per the area and species has been shown in table 1 .

All the samples were subjected to RBPT, STAT and I-ELISA. Upon analysis of 75 human serum samples, an overall prevalence of $1.33 \%$ (Tables 3 and 4) was obtained whereas 2 (2.66\%), 1(1.33\%) and $4(5.33 \%)$ samples were found positive to RBPT, STAT and I-ELISA, respectively, in individual test (Table 5).

In case of humans, out of three age groups of 20-35, 36-50 and 51-65 yr, 36-50yr persons recorded highest prevalence with the values as $3.33 \%, 0.0 \%$ and $10.0 \%$ for RBPT, STAT and I-ELISA, respectively (Table 6).

Conversely, in humans, males observed higher prevalence over females and none of the female samples was detected positive by any test (Table 7).

Odds ratio which depicts risk factor for acquiring the disease was found to be most susceptible among the 36-50 year age group individuals were found most susceptible (Table 8). 
The results obtained in different serological tests viz., RBPT, STAT and I-ELISA were analyzed statistically in terms of (a) relative sensitivity (b) relative specificity (c) accuracy, (d) positive predictive value, (e) negative predictive value, (f) positive likelihood ratio, (g) negative likelihood ratio, (h) Kappa values and by analyzing the presence of anti-Brucella antibodies in different tests combinations. The relative sensitivities and specificities of the tests were calculated using the method described by Mcdiarmid and Hellstrom (1987) (Tables 911).

As I-ELISA are the prescribed test for international trade (OIE Manual, 2009 a, b) in human the statistical analysis was done by taking I-ELISA as standard. The same pattern was followed in human as well.

Upon screening of human (75) sera samples by RBPT, STAT and I-ELISA, the results obtained were compiled in different tests combinations as shown in table 5 and 11 .

In humans, out of 75 samples tested, 2 samples were exclusively positive to IELISA. One sample positive to both RBPT and I-ELISA was observed while none of the samples were positive exclusively in RBPT and STAT. Interestingly, one sample was found positive in all the three tests (Table 5).

In humans ( $\mathrm{n}=75), \mathrm{RBPT}$ recorded $50 \%$ sensitivity with $100 \%$ specificity, $100 \%$ positive predictive value, $97.26 \%$ negative predictive value and infinite positive likelihood ratio. Similarly, STAT recorded $25 \%$ sensitivity with $100 \%$ specificity, $100 \%$ positive predictive value, $95.94 \%$ negative predictive value and infinite positive likelihood ratio. However, negative likelihood ratio was observed higher in STAT than RBPT (Table 9).
In humans ( $\mathrm{n}=75)$, RBPT (97.33\%) was having high accuracy value than STAT $(96 \%)$ using I-ELISA as standard (Table 10).

In the present study the 75 human sera samples were examined and revealed an overall prevalence of $1.33 \%$ which was lower than that of Sharma (2010) in Jammu who found overall prevalence of $3.12 \%$ in humans. The prevalence in humans was also lower than that of Sharma et al., (2016) who found $4.96 \%$ in Jammu, higher to that of $0.8 \%$ reported by Kadri et al., (2000) in Kashmir.

Test wise, 2 (2.66\%), 1(1.33\%) and 4 (5.33\%) samples were found positive to RBPT, STAT and I-ELISA, respectively. The values are significantly lower than that of Pathak et al., (2014) in Goa who observed 4.25\%, 3.54\% and $6.02 \%$ seroprevalence by RBPT, STAT and I-ELISA respectively and also to Sharma (2010) in Jammu who found 3.12\%, 0.00\% and $21.80 \%$, samples were positive to RBPT, STAT and I-ELISA, respectively.

The results were also lower than that of Sharma et al., (2016) who found 9.91\%, 9.09\% and $16.52 \%$ samples were found positive to individual tests viz., RBPT, STAT and IELISA, respectively

The age wise analysis of data in humans, the highest prevalence was observed in the 36-50 yr age group (3.33, 0.0 , and $10.0 \%$ by RBPT, STAT and I-ELISA, respectively which could be due to their higher occupational exposure to animal rearing and managemental practices.

The results are differing from that of Sharma (2010), the highest prevalence was observed in the 31-40 yr age group (8.30, 0.0, and 50.00\% by RBPT, STAT and I-ELISA, respectively) and also to Sharma et al.,(2016) who found higher prevalence in 20-35 yr age group. 
Table.1 Age-wise distribution of human serum samples

\begin{tabular}{|c|c|c|}
\hline $\begin{array}{c}\text { Species } \\
\text { (No. of samples) }\end{array}$ & $\begin{array}{c}\text { Age-group } \\
(\mathrm{yr})\end{array}$ & No. of samples \\
\hline \multirow{2}{*}{$\begin{array}{c}\text { Human } \\
\text { (75) }\end{array}$} & $20-35$ & 20 \\
\cline { 2 - 3 } & $36-50$ & 30 \\
\cline { 2 - 3 } & $51-65$ & 25 \\
\hline
\end{tabular}

Table.2 Sex-wise distribution of human serum samples

\begin{tabular}{|c|c|c|}
\hline $\begin{array}{c}\text { Species } \\
\text { No. of samples) }\end{array}$ & Sex & No. of samples \\
\hline $\begin{array}{c}\text { Human } \\
(75)\end{array}$ & Male & 45 \\
\cline { 2 - 3 } & Female & 30 \\
\hline
\end{tabular}

Table.3 Sero-prevalence of brucellosis in humans

\begin{tabular}{|c|c|c|c|}
\hline $\begin{array}{c}\text { Species } \\
\text { (No. of samples) }\end{array}$ & $\begin{array}{c}\text { RBPT } \\
\text { Positive (\%) }\end{array}$ & $\begin{array}{c}\text { STAT } \\
\text { Positive (\%) }\end{array}$ & $\begin{array}{c}\text { I-ELISA } \\
\text { Positive (\%) }\end{array}$ \\
\hline $\begin{array}{c}\text { Human } \\
(75)\end{array}$ & 2 & 1 & 4 \\
\hline
\end{tabular}

Table.4 Overall sero-prevalence of brucellosis in humans

\begin{tabular}{|r|c|c|c|}
\hline Species & Samples examined & Samples positive & $\%$ positive \\
\hline Human & 75 & 1 & 1.33 \\
\hline
\end{tabular}

Table.5 Sero-prevalence of brucellosis among humans $(n=75)$ in different places of border areas of Jammu as detected by RBPT, STAT, I-ELISA

\begin{tabular}{|c|c|c|c|c|c|c|}
\hline TESTS & \multicolumn{2}{|c|}{ RBPT } & \multicolumn{2}{|c|}{ STAT } & \multicolumn{2}{|c|}{ I-ELISA } \\
\hline $\begin{array}{c}\text { PLACE } \\
\text { (Numberof Samples) }\end{array}$ & Positive (\%) & $\begin{array}{l}\text { Negative } \\
\quad(\%)\end{array}$ & $\begin{array}{l}\text { Positive } \\
(\%)\end{array}$ & $\begin{array}{l}\text { Negative } \\
(\%)\end{array}$ & $\begin{array}{l}\text { Positive } \\
\quad(\%)\end{array}$ & $\begin{array}{l}\text { Negative } \\
\quad(\%)\end{array}$ \\
\hline $\begin{array}{l}\text { Vijaypur, Samba } \\
\text { (10) }\end{array}$ & $\begin{array}{c}0 \\
(0.00)\end{array}$ & $\begin{array}{c}10 \\
(100.0)\end{array}$ & $\begin{array}{c}0 \\
(0.00)\end{array}$ & $\begin{array}{c}10 \\
(100.0)\end{array}$ & $\begin{array}{c}0 \\
(0.00)\end{array}$ & $\begin{array}{c}10 \\
(100.0)\end{array}$ \\
\hline $\begin{array}{l}\text { RS Pura, Jammu } \\
\text { (10) }\end{array}$ & $\begin{array}{c}0 \\
(0.00)\end{array}$ & $\begin{array}{c}10 \\
(100.0)\end{array}$ & $\begin{array}{c}0 \\
(0.00)\end{array}$ & $\begin{array}{c}10 \\
(100.0)\end{array}$ & $\begin{array}{c}0 \\
(0.00)\end{array}$ & $\begin{array}{c}10 \\
(100.0)\end{array}$ \\
\hline $\begin{array}{l}\text { Kanachak, Akhnoor } \\
\text { (10) }\end{array}$ & $\begin{array}{c}1 \\
(10.0)\end{array}$ & $\begin{array}{c}9 \\
(90.00)\end{array}$ & $\begin{array}{c}1 \\
(10.0)\end{array}$ & $\begin{array}{c}9 \\
(90.00)\end{array}$ & $\begin{array}{c}1 \\
(10.0)\end{array}$ & $\begin{array}{c}9 \\
(90.00)\end{array}$ \\
\hline $\begin{array}{l}\text { Veterinary Professionals/Animal Handlers } \\
(10)\end{array}$ & $\begin{array}{c}1 \\
(10.0)\end{array}$ & $\begin{array}{c}9 \\
(90.00)\end{array}$ & $\begin{array}{c}0 \\
(0.00)\end{array}$ & $\begin{array}{c}10 \\
(100.0)\end{array}$ & $\begin{array}{c}1 \\
(10.0)\end{array}$ & $\begin{array}{c}9 \\
(90.00)\end{array}$ \\
\hline $\begin{array}{l}\text { Community Health Centre RS Pura } \\
\text { (35) }\end{array}$ & $\begin{array}{c}0 \\
(0.00)\end{array}$ & $\begin{array}{c}35 \\
(100.0)\end{array}$ & $\begin{array}{c}0 \\
(0.00)\end{array}$ & $\begin{array}{c}35 \\
(100.0)\end{array}$ & $\begin{array}{c}2 \\
(5.71)\end{array}$ & $\begin{array}{c}33 \\
(94.28)\end{array}$ \\
\hline $\begin{array}{c}\text { TOTAL } \\
\text { (75) }\end{array}$ & $\begin{array}{c}2 \\
(1.71)\end{array}$ & $\begin{array}{c}73 \\
(97.33)\end{array}$ & $\begin{array}{c}1 \\
(1.33)\end{array}$ & $\begin{array}{c}74 \\
(98.66)\end{array}$ & $\begin{array}{c}4 \\
(5.33)\end{array}$ & $\begin{array}{c}71 \\
(94.66)\end{array}$ \\
\hline
\end{tabular}


Table.6 Age-wise sero-prevalence of brucellosis in humans

\begin{tabular}{|l|c|c|c|c|}
\hline $\begin{array}{c}\text { Age } \\
\text { Group }\end{array}$ & No. of persons & $\begin{array}{c}\text { RBPT +ve } \\
(\boldsymbol{\%})\end{array}$ & $\begin{array}{c}\text { STAT +ve } \\
(\boldsymbol{\%})\end{array}$ & $\begin{array}{c}\text { I-ELISA +ve } \\
(\boldsymbol{\%})\end{array}$ \\
\hline $20-35$ & 20 & $\begin{array}{c}0 \\
(0.0)\end{array}$ & $\begin{array}{c}0 \\
(0.0)\end{array}$ & $\begin{array}{c}0 \\
(0.0)\end{array}$ \\
\hline $36-50$ & 30 & $\begin{array}{c}1 \\
(3.33)\end{array}$ & $\begin{array}{c}0 \\
(0.0)\end{array}$ & $\begin{array}{c}3 \\
(10.0)\end{array}$ \\
\hline $51-65$ & 25 & $\begin{array}{c}1 \\
(4.0)\end{array}$ & $\begin{array}{c}1 \\
(4.0)\end{array}$ & $\begin{array}{c}1 \\
(4.0)\end{array}$ \\
\hline
\end{tabular}

Table.7 Sex-wise sero-prevalence of brucellosis in humans

\begin{tabular}{|c|c|c|c|}
\hline $\begin{array}{c}\text { Sex } \\
\text { (No. of samples) }\end{array}$ & $\begin{array}{c}\text { RBPT +ve } \\
(\boldsymbol{\%})\end{array}$ & $\begin{array}{c}\text { STAT +ve } \\
(\boldsymbol{\%})\end{array}$ & $\begin{array}{c}\text { I-ELISA +ve } \\
(\boldsymbol{\%})\end{array}$ \\
\hline $\begin{array}{c}\text { Male } \\
(60)\end{array}$ & 2 & 1 & 4 \\
$(3.33)$ & $(1.66)$ & $(6.66)$ \\
\hline $\begin{array}{c}\text { Female } \\
(15)\end{array}$ & - & - & - \\
\hline
\end{tabular}

Table.8 Age wise Odds ratio in humans

\begin{tabular}{|c|c|c|c|}
\hline Age(yr) & $20-35$ & $36-50$ & $51-65$ \\
\hline & & 0.00 & 0.00 \\
$20-35$ & - & $95 \% \mathrm{CI}=0.00-3.43$ & $95 \% \mathrm{CI}=0.00-22.56$ \\
& & $\mathrm{P}-$ value $=0.27$ & $\mathrm{P}-$ value $=1.0$ \\
\hline \multirow{2}{*}{$36-50$} & - & - & 2.67 \\
& & - & $95 \% \mathrm{CI}=0.22-71.39$ \\
& - & $-\mathrm{P}-$ value $=0.62$ \\
\hline $51-65$ & - & & - \\
\hline
\end{tabular}

Using I-ELISA as standard

Table.9 Statistical analysis of RBPT and STAT taking I-ELISA as standard in humans $(n=75)$

\begin{tabular}{|c|c|c|c|c|c|c|c|}
\hline Test & $\begin{array}{c}\text { Kappa } \\
\text { Value }\end{array}$ & $\begin{array}{c}\text { Relative } \\
\text { sensitivity }(\%)\end{array}$ & $\begin{array}{c}\text { Relative } \\
\text { specificity } \\
(\%)\end{array}$ & $\begin{array}{c}\text { +ve predictive } \\
\text { value } \\
(\%)\end{array}$ & $\begin{array}{c}\text {-ve predictive } \\
\text { value } \\
(\%)\end{array}$ & $\begin{array}{c}\text { +ve likelihood } \\
\text { ratio }\end{array}$ & $\begin{array}{c}\text {-ve likelihood } \\
\text { ratio }\end{array}$ \\
\hline RBPT & 0.65 & 50 & 100 & 100 & 97.26 & Inf & 0.50 \\
\hline STAT & 0.39 & 25 & 100 & 100 & 95.94 & Inf & 0.75 \\
\hline
\end{tabular}

Table.10 Accuracy of RBPT and STAT taking I-ELISA as standard in humans $(\mathrm{n}=75)$

\begin{tabular}{|l|c|}
\hline Test & Accuracy $(\%)$ \\
\hline RBPT & 97.33 \\
\hline STAT & 96 \\
\hline
\end{tabular}


Table.11 Presence of anti-Brucella antibodies in different serological test combinations in humans $(\mathrm{n}=75)$

\begin{tabular}{|c|r|r|r|r|r|r|r|r|}
\hline Test & 1 & 2 & 3 & 4 & 5 & 6 & 7 & 8 \\
\hline RBPT & - & + & - & - & + & - & + & + \\
\hline STAT & - & - & + & - & + & + & - & + \\
\hline I-ELISA & - & - & - & + & - & + & + & + \\
\hline $\begin{array}{c}\text { Total } \\
(75)\end{array}$ & 71 & 0 & 0 & 2 & 0 & 0 & 1 & 1 \\
\hline
\end{tabular}

Sex wise studies revealed the prevalence was higher in males $(3.33,1.66$ and $6.66 \%$ by RBPT, STAT and I-ELISA, respectively) as compared to females ( $0.0 \%$ by all 3 tests). This is in accordance with Sharma (2010) who reported higher prevalence in males $(4.00,0.00$ and $28.0 \%$ by RBPT, STAT and I-ELISA, respectively) as compared to females $(0.0 \%$ by all 3 tests) and also to Sharma et al., (2016) who also found higher prevalence in males. However, in present study, the difference in the sero-positivity between males and females is statistically not significant which may be due to less number of female samples in occupationally-exposed group.

In the present study, on testing 75 samples of humans by RBPT, STAT and I-ELISA, the maximum number of samples was found positive by I-ELISA, followed by RBPT and least by STAT in human. The results of these tests were compiled in different tests combinations and upon analysis of these combinations, 8 samples of goats and 2 of humans were found exclusively positive to IELISA. This high sero-positivity exclusively to I-ELISA could only be best ascribed in its (IELISA) nature being a primary binding assay which can detect $1 / 100^{\text {th }}$ of the antibodies to those detected by secondary binding assay i.e., CFT (Tizard,1982). Moreover, the many epitopes of S-LPS (antigen used in I-ELISA in present study) make it a highly sensitive test in brucellosis serology. Further, the above finding was supported by the work of Cargill et al., (1985) who revealed that some culture positive animals were negative in RBPT while positive by I-ELISA.
Conversely, not a single sample exclusively positive to RBPT was detected in, both, goats and human beings. The sensitivity of RBPT was $20 \%$ in goats while $50 \%$ in humans with high specificity values. These findings can only be best supported by the fact that RBPT is an oversensitive test for diagnosis in individual animals especially those vaccinated (MacMillan, 1990) and false negative reactions may occur due to prozone phenomenon (Nielsen, 2002). Further, in field conditions the sensitivity of RBPT is known to vary from antigen to antigen preparation as reported by Blasco et al., (1994) who reported significant differences in sensitivity of RBPT antigens from different manufacturing sources. Similarly, Stryszak (1986) also reported RBPT to be a less sensitive and observed the sensitivity to be increased when the amount of RBPT antigen was reduced to half. In India, too, there are number of reports regarding lower sensitivity of RBPT (Singh, 2009; Sharma et al., 2015) viz., Rajkhowa et al., (2005) observed it to be $33.3 \%$ during investigation in mithuns. Nevertheless, I-ELISA was observed to be a more sensitive test over RBPT and STAT and should be applied on a large scale to evaluate it for screening purposes for diagnosis of brucellosis in the country. In conclusion, in comparison to RBPT and STAT, I-ELISA was found to be most sensitive and detected maximum number of sera samples in human beings.

\section{References}

Alton, G.G., Jones, L.M. and Pietz, D.E. 1975. Laboratory Techniques in Brucellosis. 
Monograph Series No. 55. WHO, Geneva, Switzerland.

Benkirane, A. 2006. Ovine and caprine brucellosis: world distribution and control/eradication strategies in west Asia/North Africa Region. Small Ruminant Res., 62: 14-25.

Blasco, J.M., Garin-Bastuji, B., Mar'yn, C.M., Gerbier, G., Fanlo, J., Jim'enez de Bag"u’es, M.P. and Cau', C. 1994. Efficacy of different Rose Bengal and Complement Fixation antigens for the diagnosis of Brucella melitensis in sheep and goats. Vet. Record, 134: 415-20.

Capasso, L. 2002. Bacteria in two-millennia-old cheese, and related epizoonoses in Roman populations. J. Infect. Dis., 45: 122-27.

Cargill, C.K., Lee, K. and Clarke, I. 1985. Use of an enzyme linked immunosorbent assay in a bovine brucellosis eradication program. Australian Vet. J., 62: 49-52.

Godfroid, J.C., Liautard, A., Kohler, J., Fretin, S., Walravens, D., Garin Basutji, K. and Letesson, J. 2005. From the discovery of Malta Fever's agent to the discovery of marine mammal reservoir, brucellosis has continuously been a re-emerging zoonoses. Vet. Res., 36: 313-26.

Kadri, S.M., Rukhsana, A., Laharwal, M.A. and Tanvir, M. 2000. Seroprevalence of brucellosis in Kashmir (India) among patients with pyrexia of unknown origin. J. Indian Med. Assoc., 98: 170-1.

McDiarmid, S.C. and Hellstrom, J.S. 1987. An intradermal test for the diagnosis of brucellosis in extensively managed cattle herds. Preventive Vet. Med., 4: 361-69.

MacMillan, A. 1990. Conventional serological tests. In: Animal brucellosis, Chapter 8.

Nielsen, K. 2002. Diagnosis of brucellosis by serology. Vet. Microbiol., 90: 47-459.
OIE Manual of standards for diagnostic tests and vaccines. 2008a. Bovine brucellosis, OIE, Paris, pp: 624-59.

Pappas, G., Akritidis, N., Bosilkovski, M. and Tsianos, E. 2005. Brucellosis. New England J. Med., 22: 2325-36.

Pathak, A.D., Dubal, Z.B., Doijad, S., Raorane, A., Rodrigues, S., Naik, R., Gaonkar, S.N., Kalorey, D.R., Kurkure, N.V., Naik, R. and Barbuddhe, S.B. 2014. Human brucellosis among pyrexia of unknown origin cases and occupationally exposed individuals in Goa Region, India. Emerging Health Threats, 7: 238-46.

Rajkhowa, S., Rahman, H., Rajkhowa. and Bujarbaruah, K. M. 2005. Seroprevalence of brucellosis in mithuns (Bosfrontalis) in India. Preventive Vet. Med., 69: 145-51.

Sharma, H.K., Kotwal, S.K., Singh, D.K., Malik, M.A., Kumar, A., Gunalan, R. and Singh, M. 2016.Seroprevalence of human brucellosis in and around Jammu, India, using different serological tests. Vet. World, 9(7): 742-46.

Sharma, P. 2010. Sero-Prevalence of Brucellosis in livestock and occupationally exposed humans in and around Jammu. M.V.Sc. thesis, Faculty of Veterinary sciences and animal husbandry, SKUAST-J, Jammu, India.

Singh, A., Agrawal, R., Singh, R., Singh, D.K. and Pande, N. 2010. Seroprevalence of brucellosis in small ruminants. Indian Vet. J., 87: 224-25.

Stryszak, A. 1986. Serological activity of antiBrucella abortus immunoglobulins in the rose bengal plate test in cattle. Polskie Archiwum Weterynaryjne, 26: 7-22.

Tizard, I. 1982. Serological assays. J. Americal Vet. Med. Assoc., 81: 1162-5.

\section{How to cite this article:}

Vijay Sharma, H.K. Sharma, Subha Ganguly, Sindhu Berian and Malik, M.A. 2017. Seroprevalence Studies of Brucellosis among Human using Different Serological Tests. Int.J.Curr.Microbiol.App.Sci. 6(5): 1793-1800. doi: https://doi.org/10.20546/ijcmas.2017.605.195 